Arab Univ. J. Agric. Sci., Ain Shams Univ., Cairo, Egypt

28(1), 217-228, 2020

Website: http://ajs.journals.ekb.eq

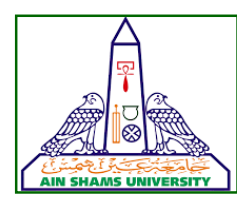

\title{
PRODUCTION OF FUNCTION YOGHURT DRINK FORTIFIED WITH DIFFERENT TYPES OF HERBAL EXTRACTS AND ITS BIOLOGICAL ATTRIBUTES IN HEPATITIS RATS
}

\author{
Al-Soudy ${ }^{1 *}$ M., E-Batawy ${ }^{2}$ O.I., Abdel Fattah ${ }^{2}$ A.A., Safaa T. Gohari ${ }^{3}$ \\ and El-Dsouky ${ }^{1}$ W.I.
}

1- Dairy Science Dept., Fac. of Agric., Al-Azhar Univ., Branch Assuite, Egypt

2- Food Science Dept., Fac. of Agric., Ain Shams Univ., P.O. Box 68, Hadayek Shoubra 11241, Cairo, Egypt

3- Food Science and Nutrition, Home Economic Dept., Fac. of Specific Education, Ain Shams Univ., Cairo, Egypt

${ }^{*}$ Corresponding author: Alsoudymohamed@gmail.com

Received 20 February, 2020

Accepted 6 May, 2020

\begin{abstract}
The present study aimed to produce function yoghurt drink fortified with different types of herbal extracts (Ginger, Amla, Curcuma) and assess its therapeutic effect in hepatitis rats. Thirty-six male albino rats randomly divided into two major groups. The $1^{\text {st }}$ group were control (-) (6 rats) was fed on a standard diet, while the $2^{\text {nd }}$ group (included 30 rats) were fed on standard diet and injected it by $\mathrm{CCl}_{4}$ "for two weeks" to prodding chronic damage in the liver (hepatitis) then divided into five groups (6 rats each group), then treated by plain drinking yoghurt and different herbal drinking yoghurt fortified with different types of herbs extract. Different Biological attributes were determined. The herbal extracts and yoghurt drink fortified with different types of herbal extracts product were evaluated the antioxidant activity, total phenolic content, chemical properties and their effects on hepatoprotective activity by determining biochemical parameters and histopathological examination. The results referred to functional flavoured drinking yoghurt containing herbal extract exhibited no significant differences were noticed in total solids, fat, protein, ash, and lactose content them control samples. Drinking yoghurt fortified with Curcuma exhibited highest content of antioxidant activity and total phenolic content among all treatments. As well as, rats fed on diet fortified with drinking yoghurt fortified with Curcuma for 4 weeks observed higher effects in potential hepatoprotective compared to liver injury control group (IC). The rats
\end{abstract}

succeeded in restoring the biochemical parameters and promoted the histological change of the liver. This improvement was partly observed in the group that received drinking yoghurt fortified with Ginger and Amla herbal extracts while, the group recipient drinking yoghurt fortified with Curcuma herbal extract were improved totally. It could be concluded that drinking yoghurt fortified with different herbal extract especially Curcuma can be used as neutral compound in functional foods for individuals who have liver diseases.

Keywords: hepatitis, $\mathrm{CCl}_{4}$, herbs, inflammatory cells, drink yoghurts fortified with extract herbs.

\section{INTRODUCTION}

Functional foods have currently risen as like a novel region of health improving products. The target function of functional foods is largely based of the ancient ingredients. The American Dietetic Association has reported that functional foods may consist of different types of foods such as enriched, fortified, while nutraceuticals are defined as isolated ingredients that can be incorporated into different food products to imrove health at levels not normaly obtainable from normal foods (Ross, 2000).

Yoghurt is certain regarding to products of dairy prepared by using lactic acid bacteria usually Streptococcus thermophilus and Lactobacillus bulgaricus to induce fermentation (Gharibzahedi and Chronakis, 2018). Yoghurt products can be categorized 
into set, stirred and drinkable yoghurt, based on their physical and texture properties. It can also be classified as plain, fruit and flavored yoghurt based on flavor and as set yoghurt, stirred yoghurt/drinking yoghurt, smoked yoghurt, concentrated yoghurt, frozen yoghurt, yoghurt drinks and beverages based on the manufacturing methods. Yoghurt drinks are a product, prepared by mixing yoghurt with milk or water with sugar, stabilizer and fruit juices. (Pohjanheimo and Sandell, 2009).

Herbs do make contributions significantly in health and human nutrition, due to it include almost all essential human nutrients. Addition of different herbals can be improving dairy product consumption, because using various herbs in dairy products production could be gives different choices to the consumers. Herbal extracts could be used in dairy products, ayurvedic formulation, pharmaceuticals, ready-to-drink mixes, dietary foods, confectionery, spices mixes, etc. So, fortification of herbs within dairy products may furnish worth addition as, functional dairy product (Lalita et al 2017).

Liver diseases are a international disease problem. The most frequent illnesses consists of infections for example hepatitis $(A)$, hepatitis $(B)$, hepatitis $(C)$, hepatitis $(E)$, fatty liver, cancer, cirrhosis, or drug damages specially by cancer drugs and acetaminophen.

Diets rich with normal antioxidants are using as a tool to inhibit and therapies liver diseases (Morisco et al 2008). The potential for amla extract as a food ingredient is increasing substantially, because of the growing global nutraceuticals and functional food market. (Jain and Khurdiya, 2004). Normal antioxidants, especially flavonoids and phenolics, are out of danger and represent bioactive components that are able to absorb and remove (free radicals - quenching singlet - triplet oxygen / decomposing peroxide group). Recent studies tend to identification of antioxidant capacity of plants wich may be used for consumers according to Raushan et al 2013. Different herbs extract could be contain high level of antioxidant component such as ginger, amla and curcuma. The use of herbs to medicate illnesses is nearly universal among non-industrialized societies and is repeatedly most available low cost than purchasing pricey contemporary pharmaceuticals.

Therefore, the recent study aimed to produce function yoghurt drink fortified with different types of herbal extracts (Ginger, Amla, Curcuma) and detected the probable anti-hepatitis effect in Albino rats against induced liver injury.

\section{MATERIALS AND METHODS}

\section{MATERIALS}

Fresh cow's milk used in drinking yoghurt preparation was purchased from herd of the dairy cattle at Agriculture Faculty, Cairo University. The milk contains (3\% fat, 3.20 proteins, $12.5 \%$ T.S.). Skim milk powder (grade medium heat for food use) produced by AGRI, BEST, Holland was obtained from the local market of Cairo. Commercial grade granulated cane sugar (Sucrose) produced by the sugar and Integrated Industries Co. at Hawamdia, Egypt. And high Methoxyi Pectin (HMP) APA102 (Yantai Andre Pectin Co.Ltd, China. Three herbs, were used under investigation namely Ginger (Zingiber Officinale), Amla (Emblica officinalis), Curcuma (Curcuma longa) were obtained from the local market.

\section{Starter cultures}

Yoghurt starter culture (YC-X11 DIP 50u) was Lactobacillus delbrueckii subsp and Streptococcus thermophilus. bulgaricus was obtained from Chr. Hansens Laboratiers, Denmark and activated at $42^{\circ} \mathrm{C}$ using $12 \%$ sterilized reconstituted skim milk. After incubation at $42^{\circ} \mathrm{C}$ for $4-5 \mathrm{~h}$, the working culture was freshly used.

\section{Preparation of herbal extracts}

Water herb extract was prepared as follow: $5 \mathrm{~g}$ of herbs powder were poured into $250 \mathrm{ml}$ conical flask in which $95 \mathrm{ml}$ boiling distilled water. The mixture was kept for $12 \mathrm{~h}$ with continuous agitation using a mechanical shaker at 30 minutes intervals. The extract was filtered using Whatman No. 1 filter paper according to the procedure of (Maduka et al 2014) to get the extract. Extracts were kept in cold storage in brown bottle.

\section{Production of yoghurt drink}

Different treatments of yoghurt drink were manufactured according to the procedure of (Thomas and Wansapala, 2017) with some alterations as followss: Fresh cow milk was used for yoghurt production and $2 \%$ skim milk powder was added to increase solids of milk.

The mix was heated to $85^{\circ} \mathrm{C}$ for $10 \mathrm{~min}$. and then rapidly cooled to $45^{\circ} \mathrm{C}$. Then $2-3 \%(\mathrm{w} / \mathrm{v})$, yoghurt culture was added, and incubated at $43^{\circ} \mathrm{C}$ till reaching to $\mathrm{pH} 4.5$. Then the product was stored in a refrigerator at $\left(5 \pm 1^{\circ} \mathrm{C}\right)$ overnight. 


\section{Production of Function yoghurt drink fortified with different types of herbal extracts and its biological attributes in hepatitis rats}

Different yoghurt drinks were prepared by adding $30 \%$ different mixes of herbal extracts, sugar and stabilizers to $70 \%$ yoghurt. The drinking yoghurt mixes filled into $250 \mathrm{~g}$ plastic cups. The resultant drinking yoghurt samples were refrigerated stored till used it in rats feeding. The samples were analyzed at 1,7 and 14 days intervals.

\section{Biological experiment}

Thirty-six male albino rats weighing about $150 \pm 5$ $g$ were purchased from Agricultural Research Center, Giza, Egypt. The animal groups were fed on standard diet and placed in an atmosphere of filtered, pathogen-free air, water and maintained at a temperature between $20-25^{\circ} \mathrm{C}$ for 8 weeks, $50 \%$ relative humidity and $12 \mathrm{~h}$ light and $12 \mathrm{~h}$ dark cycle. The rats were adapted for 1 week as an adaptation period, then were divided into randomly 2 groups, the $1^{\text {st }}$ group of rats (6 rats) represent as control (-) as seen in Table A. while, the $2^{\text {nd }}$ group thirty rats was injected twice per week with $\left(\mathrm{CCl}_{4}\right)$ in paraffin oil ( $50 \% \mathrm{v} / \mathrm{v} 2 \mathrm{ml} / \mathrm{kg}$ ) by subcutaneous injection (for two weeks) to induce chronic damage in the liver as described by (Jayasekhar et al 1997). After 2 weeks the animals were divided into five groups (each group contain six rats). The first group from hepated rats was fed on standard diet and served as control (+). While the remaining groups (4) were fed on commercial diet containing yoghurt drink fortified with different types of herbs extract $(30 \%)$ by epigastric tube for 4 weeks as seen in Table (B). The rats were weighed weekly and at the end of the experimental feeding period, then were fasted overnight, anesthetized with ether and sacrificed for analysis. The following steps were done in 6 rats after 8 weeks of treatment in each group:

* Blood samples were withdrawn from orbital plexus venous and were collected into plain tubes without anticoagulant and allowed to clot. They were centrifuged at $3000 \mathrm{rpm}$ for ten $\min$ at four ${ }^{\circ} \mathrm{C}$, to obtain clear serum that was frozen at $-18^{\circ} \mathrm{C}$ until analyzed. *Animals were anesthetized with ether and sacrificed, quickly dissected to excise the liver, kidney. These organs were weighed and then kept in $10 \%$ formaldehyde until histological investigations.
Table A. Composition of commercial diet

\begin{tabular}{|l|c|}
\hline \multicolumn{1}{|c|}{ Ingredients } & Percentage \% \\
\hline Protein: [soy flour meal + & 21.00 \\
sun flower meal + gluten] & 3.26 \\
Fat & 3.29 \\
Crude fiber & 0.40 \\
DI. Methionine & 1.00 \\
Vitamins mixed & 4.00 \\
Minerals mixed & 67.05 \\
Carbohydrates & \\
\hline
\end{tabular}

Table B. Experimental diets.

\begin{tabular}{|c|c|}
\hline Groups & Experimental diets \\
\hline Control (-) & Standard diet (-) \\
\hline Control (+) & ${ }^{*} \mathrm{Ccl}_{4}($ control +$)+$ Standard diet \\
\hline Yoghurt & $\begin{array}{l}{ }^{*} \mathrm{ccl}_{4}+\text { Standard diet }+5 \mathrm{ml} \text { (yoghurt } \\
\text { drink by epi gastric tube) }\end{array}$ \\
\hline Ginger & $\begin{array}{l}{ }^{*} \mathrm{Ccl}_{4}+\text { Standard diet }+5 \mathrm{ml} \text { (yoghurt } \\
\text { drink }+30 \% \text { Ginger extract, yoghurt } \\
\text { drink by epi gastric tube) }\end{array}$ \\
\hline Amla & $\begin{array}{l}{ }^{*} \mathrm{ccl}_{4}+\text { Standard diet }+5 \mathrm{ml} \text { (yoghurt } \\
\text { drink }+30 \% \text { Amla extract, yoghurt } \\
\text { drink by epi gastric tube) }\end{array}$ \\
\hline Curcuma & $\begin{array}{l}{ }^{*} \mathrm{ccl}_{4}+\text { Standard diet }+5 \mathrm{ml} \text { (yoghurt } \\
\text { drink }+30 \% \text { curcuma extract, yoghurt } \\
\text { drink by epi gastric tube) }\end{array}$ \\
\hline
\end{tabular}

* subcutaneous injection

\section{Analytical Methods}

\section{Chemical properties}

The total solid (TS), total protein (TP), fat, ash, and lactose contents of drinking yoghurt samples were determined according to (AOAC, 2012). Total phenolic contents (TPC) were determined in extracts by using Folin-Ciocalteu reagent as described by (Odabasoglu et al 2004). While, yoghurt drink samples were determined by using an assay applied by (Maksimovic et al 2005). FRAP was determined in extract according to the method described by (Benzie and Strain, 1996). The antioxidant 
activity was determined in herbal extracts using 1,1diphenyl-2-picrylhydrazyl radical (DPPH) using spectrophotometrically method (Shetty et al 2007). Antioxidant activity of yoghurt drink samples during storage period were determined by method of (Vijayalakshmi et al 2014).

\section{Biological Determination}

Biological evaluation of tested diets was carried by determination of food intake, percentage of body weight gain (BWG \%) and organs weight / body weight as described by (Chapman et al 1959).

BWG\% $=$ [Final weight-Initial weight / Initial weight $]$ $X 100$

Organ weight/ body weight $\%=($ Organ weight $/ \mathrm{Fi}-$ nal weight) X 100

\section{Serum biochemical analysis}

Serum samples were examined for detection the amount of uric acid, creatinine, and serum urea nitrogen for enzyme activities of aspartate aminotransferase (AST) and alanine aminotransferase (ALT), by biodiagnostic kits.

Serum Uric Acid was determined by (Barham and Trinder, 1972) using spectrophotometer (model DU 4700) adjusted at $510 \mathrm{~nm}$. Serum urea nitrogen was determined as described by (Fawcett and Soctt, 1960) using spectrophotometer adjusted at $550 \mathrm{~nm}$. Serum creatinine was determined by (Larsen, 1972) using spectrophotometer adjusted at $510 \mathrm{~nm}$. ALT and AST activities were determined colorimetrically using spectrophotometer at $505 \mathrm{~nm}$ as described by (Reitman and Frankel, 1957).

\section{Histopathology technique}

Tissues of liver and kidney were fixed immediately after dissection in 10\% neutral formalin for 24 $\mathrm{h}$, then dehydrated in ascending concentration of alcohol, cleaned in xyline and embedded in paraffin wax. Tissues were sectioned at a thickness of $3 \mathrm{mi}-$ cron and stained with hematoxylin and fosin stains. Histopathological alteration of tissues were examined by the light microscope.

\section{Statistical analysis}

Data of Mean body weight gain, Mean organs weight / body weight \% and Blood chemical analysis of experimental rats (Mean values of 6th replicates). Analyzed using One Way ANOVA. All statistical analysis for the different traits was realized using SAS program (SAS, 1999).

\section{RESULTS AND DISSCUSION}

\section{Physiochemical properties of different herbal extracts}

The results listed in Table (1) demonstrate there aren't any significant differences in TS, fat, TP, ash, acidity and $\mathrm{pH}$ values among all studied herbal extracts. Significant differences were observed in total phenolic content, scavenging activity and FRAB among all herbal extracts. Curcuma, ginger and amla extracts could be as source of total phenolic content and free radical scavenging. These results are agree with those obtained by (Maizura, 2011).

Who found that ginger, turmeric and kesum extracts have significant difference in antioxidant activity and total phenolic content.

Table 1. Properties of different types of herbal extracts

\begin{tabular}{|c|c|c|c|}
\hline \multirow{2}{*}{ Properties } & \multicolumn{3}{|c|}{ Type of herbal extract } \\
\cline { 2 - 4 } & Ginger & Amla & Curcuma \\
\hline TS (\%) & $4.25^{\mathrm{a}}$ & $4.20^{\mathrm{a}}$ & $4.35^{\mathrm{a}}$ \\
Fat (\%) & $0.19^{\mathrm{a}}$ & $0.02^{\mathrm{a}}$ & $0.25^{\mathrm{a}}$ \\
TP (\%) & $0.25^{\mathrm{a}}$ & $0.30^{\mathrm{a}}$ & $0.32^{\mathrm{a}}$ \\
Ash (\%) & $0.19^{\mathrm{a}}$ & $0.18^{\mathrm{a}}$ & $0.18^{\mathrm{a}}$ \\
pH values & $7.5^{\mathrm{a}}$ & $7.6^{\mathrm{a}}$ & $7.4^{\mathrm{a}}$ \\
Acidity (\%) & $0.21^{\mathrm{a}}$ & $0.20^{\mathrm{a}}$ & $0.23^{\mathrm{a}}$ \\
Total phenolic (mg & $101.60^{\mathrm{b}}$ & $55.00^{\mathrm{c}}$ & $174.00^{\mathrm{a}}$ \\
GAE/100g) & & & \\
Scavenging activity \% & $56.47^{\mathrm{b}}$ & $51.93^{\mathrm{c}}$ & $67.35^{\mathrm{a}}$ \\
FRAB (OD) & $33.60^{\mathrm{b}}$ & $23.17^{\mathrm{c}}$ & $41.26^{\mathrm{a}}$ \\
\hline
\end{tabular}

- Means in the same row with different litters are significantly different $(p<0.05)$.

FRAP: Ferric reducing antioxidant

Chemical composition of flavored yoghurt drinks fortified with different types of herbal extracts

The data in Table (2) showed that there aren't any significant differences between functional flavoured drinking yoghurt containing herbal extract and control treatment in total solids, fat, protein, ash, and lactose contents. This is may be due to the little ratio of the herbal extract added to yoghurt drink. These data agree with the data obtained with (Mahmoud et al 2012) who found that treatments 

herbal extracts and its biological attributes in hepatitis rats

of soft cheese fortified with ginger extract haven't significant difference in TS, fat and TP.

Table 2. Chemical composition of flavored yoghurt drinks fortified with different types of herbal extracts

\begin{tabular}{|c|c|c|c|c|}
\hline Properties & Control & T1 & T2 & T3 \\
\hline TS (\%) & $16.82^{\mathrm{a}}$ & $17.71^{\mathrm{a}}$ & $17.75^{\mathrm{a}}$ & $17.80^{\mathrm{a}}$ \\
Fat (\%) & $2.4^{\mathrm{a}}$ & $2.5^{\mathrm{a}}$ & $2.5^{\mathrm{a}}$ & $2.5^{\mathrm{a}}$ \\
TP (\%) & $3.24^{\mathrm{a}}$ & $3.31^{\mathrm{a}}$ & $3.30^{\mathrm{a}}$ & $3.28^{\mathrm{a}}$ \\
Ash (\%) & $0.74^{\mathrm{a}}$ & $0.751^{\mathrm{a}}$ & $0.750^{\mathrm{a}}$ & $0.757^{\mathrm{a}}$ \\
Lactose (\%) & $3.54^{\mathrm{a}}$ & $3.59^{\mathrm{a}}$ & $3.61^{\mathrm{a}}$ & $3.60^{\mathrm{a}}$ \\
\hline
\end{tabular}

Control yoghurt drink without any herbal extracts.

- T1,T2,T3 herbal yoghurt drink fortified with ginger, amla and curcuma extracts respectively.

The results listed in (Table 3) show there are significant differences in scavenging activity and TPC among all treatments. Functional drinking yoghurt fortified with herb extracts has antioxidant activity higher than control.

This is may be due to the high antioxidants activity in herb extract added to flavoured drinking yoghurt. These results are in agreement with (Davinder, 2012). Who found that incorporation of ginger juice in ice cream at different levels significantly affected the antioxidant activity and total phenols. The total phenols contents were highest in functional drinking yoghurt fortified with curcuma extract followed by ginger then amla herbs. This differences in phenol component among all functional drinking yoghurt fortified with different types of herbal extract may be due to the differences in total phenolic contents of added herbs. The results are in agreement with (Swelem, 2015). Total phenols contents in all samples were decreased as the refrigerated storage period progressed up to 14 days. It is possible that most of the degradation of total phenols resulted from of oxidation reactions. Same trend have been reported by (Khalil, 2013) and (ELSamahy et al 2014) who found that, the total phenolic compounds decreased ( $p \leq 0.05)$ in all treatments during the storage period. (Hallim et al 2019). The antioxidant activity and TPC have significant differences in all samples $(P<0.05)$. Addition of pomegranate and cactus pear juices led to significant increase in TPC and antioxidant activity of yoghurt treatments in contrast along the control sample.
Table 3. Antioxidant activity and Total phenolic content (TPC) of yoghurt drinks fortified with different types of herbs extract during storage at $5 \pm 1^{\circ} \mathrm{C}$ for 14 days

\begin{tabular}{|c|c|c|c|}
\hline \multirow{2}{*}{ Treatments } & \multicolumn{3}{|c|}{ Storage periods } \\
\cline { 2 - 4 } & Fresh & 7 & 14 \\
\hline \multicolumn{4}{|c|}{ Scavenging activity (\%) } \\
\hline Control & $18.3^{\mathrm{a}}$ & $15.86^{\mathrm{b}}$ & $9.52^{\mathrm{c}}$ \\
T1 & $35.4^{\mathrm{a}}$ & $32.02^{\mathrm{b}}$ & $25.12^{\mathrm{c}}$ \\
T2 & $33.8^{\mathrm{a}}$ & $30.11^{\mathrm{b}}$ & $23.50^{\mathrm{c}}$ \\
T3 & $41.1^{\mathrm{a}}$ & $34.67^{\mathrm{b}}$ & $27.59^{\mathrm{c}}$ \\
\hline \multicolumn{3}{|c|}{ Total phenolic (mg GAE/100g) } \\
\hline Control & $\mathrm{ND}$ & $\mathrm{ND}$ & $\mathrm{ND}$ \\
T1 & $30.48^{\mathrm{a}}$ & $22.15^{\mathrm{b}}$ & $17.2^{\mathrm{c}}$ \\
T2 & $16.5^{\mathrm{a}}$ & $15.3^{\mathrm{b}}$ & $11.9^{\mathrm{c}}$ \\
T3 & $52.2^{\mathrm{a}}$ & $35.18^{\mathrm{b}}$ & $20.11^{\mathrm{c}}$ \\
\hline
\end{tabular}

*See table (2) for details

Biological Evaluation of yoghurt drinks fortified with different types of herb extracts

\section{Body and organs weights}

The changes in rats body weight is usually a very sensitive indicator of rats well-being it integrates many other parameters and usually, in particular, food consumption. Increase in weight gain compared to control may not be due to an adverse effect; but due to a nutritionally rich balanced diet in the animal feed.

Result in Table (4) showed that, significant differences $(P \leq 0.05)$ were observed in the final body weight of animal rats between the control (+) group $(209.0 \pm 6.792)$ and the remaining treatment groups. Yoghurt drink + curcuma extract group should the best result. Also, data revealed that the body weight gain per week (BWG/wk) was recorded highest $(45.49 \mathrm{~g})$ for the control (-) group while the body weight gain per week for the remaining treatment groups with drink yoghurt fortified with different types of herb extract ranged between 30.09 and $37.73 \mathrm{~g}$ as seen in the same Table. The lowest rates of body weight gain per week occurred in control (+) group $(27.85 \mathrm{~g})$, while the best increase in body weight gain per week were $(37.73 \pm 1.558$ in yoghurt drink + curcuma extract group followed yoghurt drink + ginger extract group (34.03 \pm 1.352$)$. 
Table 4. Mean body weight gain $(\mathrm{g})$ of rats fed on yoghurt drink fortified with different types of herb extract.

\begin{tabular}{|c|c|c|c|c|c|c|}
\hline \multirow{3}{*}{$\begin{array}{c}\text { Body weight } \\
\text { (g) }\end{array}$} & \multicolumn{6}{|c|}{ Groups } \\
\hline & \multirow[t]{2}{*}{ Control (-) } & \multirow[t]{2}{*}{ Control (+) } & \multirow[t]{2}{*}{ Yoghurt (g) } & \multicolumn{3}{|c|}{$\begin{array}{c}\text { Yoghurt + different types of extract herbs } \\
(30 \%)\end{array}$} \\
\hline & & & & Ginger & Amla & Curcuma \\
\hline IBW & $164.0^{a} \pm 8.408$ & $163.3^{a} \pm 3.964$ & $163.0^{\mathrm{a}} \pm 4.351$ & $165.8^{a} \pm 4.386$ & $163.5^{a} \pm 4.500$ & $163.3^{a} \pm 3.756$ \\
\hline After $7 d$ & $174.0^{a} \pm 9.132$ & $170.3^{a} \pm 4.310$ & $171.0^{a} \pm 4.676$ & $177.0^{a} \pm 6.285$ & $171.0^{\mathrm{a}} \pm 4.374$ & $170.5^{a} \pm 4.433$ \\
\hline After 14d & $183.8^{a} \pm 9.997$ & $177.5^{\mathrm{a}} \pm 4.667$ & $179.0^{a} \pm 5.459$ & $189.0^{a} \pm 8.106$ & $178.7^{a} \pm 4.287$ & $179.3^{a} \pm 4.372$ \\
\hline After 21d & $194.0^{a} \pm 10.89$ & $185.0^{\mathrm{a}} \pm 5.099$ & $187.2^{\mathrm{a}} \pm 5.582$ & $198.2^{a} \pm 9.620$ & $186.7^{a} \pm 4.356$ & $187.0^{a} \pm 4.775$ \\
\hline After 28d & $204.0^{a} \pm 11.66$ & $192.5^{\mathrm{a}} \pm 5.371$ & $195.0^{\mathrm{a}} \pm 6.434$ & $206.4^{\mathrm{a}} \pm 9.963$ & $194.3^{\mathrm{a}} \pm 4.499$ & $196.0^{a} \pm 5.247$ \\
\hline After 35d & $214.6^{a} \pm 12.64$ & $200.7^{a} \pm 5.829$ & $203.5^{\mathrm{a}} \pm 6.941$ & $214.8^{\mathrm{a}} \pm 10.50$ & $202.8^{\mathrm{a}} \pm 4.438$ & $203.5^{\mathrm{a}} \pm 5.852$ \\
\hline After 42d & $225.4^{a} \pm 13.16$ & $209.0^{\mathrm{a}} \pm 6.006$ & $212.2^{\mathrm{a}} \pm 7.432$ & $230.2^{\mathrm{a}} \pm 7.419$ & $210.8^{a} \pm 4.354$ & $212.5^{\mathrm{a}} \pm 6.147$ \\
\hline FBW & $238.8^{a} \pm 14.67$ & $209.0^{\mathrm{b}} \pm 6.792$ & $211.5^{b} \pm 6.179$ & $222.4^{\mathrm{ab}} \pm 7.698$ & $212.2^{b} \pm 5.082$ & $225.2^{\mathrm{ab}} \pm 7.282$ \\
\hline BWG/wk & $45.49^{a} \pm 4.168$ & $27.85^{\mathrm{c}} \pm 1.566$ & $29.76^{b c} \pm 1.827$ & $34.03^{b c} \pm 1.352$ & $30.09^{b c} \pm 3.780$ & $37.73^{b} \pm 1.558$ \\
\hline
\end{tabular}

The data in (Table 5) show that the weight of liver and kidney in the treatment groups with yoghurt drinks fortified with different herb extracts and yoghurt drink only were lower than control $(+)$ group $(P \leq 0.05)$. An increase in liver and kidney/body weight of animals that treated with $\mathrm{CCL}_{4}$ can be noticed.

\section{Biochemical analysis}

The data in (Table 6) observe there are a significant decrease $(P \leq 0.05)$ in total protein and a significant increase $(P \leq 0.05)$ in liver enzymes in rats administered with $\mathrm{CCl}_{4}$ (control +) compared with (control -) group. The results indicate that injection of rats with $\mathrm{CCl}_{4}$ caused acute liver damage. The previous studies mentioned that $\mathrm{CCl}_{4}$ has bad effects of on liver function (Huo et al 2011). The same table shows that a significant decrease $(P \leq 0.05)$ in liver enzyme in all groups injected by $\mathrm{CCl}_{4}$ and fed on drink yoghurts fortified with different types of herb extracts and yoghurt drink only as compared to the control (+) group. On the other hand There weren't any significant differences in, (drink yoghurt $+30 \%$ ginger extract, drink yoghurt $+30 \%$ amla extract and drink yoghurt only) groups, except (drink yoghurt + $30 \%$ curcuma extract group) has significant increase in serum total protein as compared with control $(+)$.
This finding is confirmed by (Barta et al 2015) Demonstrated the normalization of the liver enzymes values in rat with the curcumin which induce accelerated regeneration of liver cells by reducing the leakiness of these enzymes in the blood stream. The protective effects may be the result of repairing and preserving the structural integrity of the hepatic cells injury caused by $\mathrm{CCl}_{4}$. (Kazeem et al 2011) showed no change in total protein in the ginger treated group contrast with the control one. Such results agree with those obtained by (Ugwuja et al 2008) who mentioned that ginger extract doesn't affect on serum protein levels.

The mean values of urea nitrogen, serum uric acid and creatinine, increased gradually with increasing the protein level in the diet. Meanwhile (Frey, 2007) mentioned that the serum urea nitrogen level will rise in case the body is using large amounts of protein or the patient's kidneys are not functioning correctly. It was noticed that from the data in table (6) the mean values of urea and creatinine decreased $(p<0.05)$, in all tested rat groups that fed on drink yoghurts fortified with different types of herb extracts and yoghurt drink only compared to control $(+)$, while there weren't any significant differences in uric acid. The previous results were significantly decreased $(P<0.05)$ of rats fed 

herbal extracts and its biological attributes in hepatitis rats

Table 5. Mean organs weight / body weight \% of rats fed on yoghurt drink fortified with different types of herb extracts $(30 \%)$

\begin{tabular}{|c|c|c|c|c|c|c|}
\hline \multirow{2}{*}{ Parameters } & \multicolumn{6}{|c|}{ Groups } \\
\cline { 2 - 7 } & \multirow{3}{*}{ Control (-) } & \multirow{2}{*}{ Control (+) } & \multirow{2}{*}{ Yoghurt (g) } & \multicolumn{2}{|c|}{ Yoghurt + different types of extract herbs } \\
\cline { 5 - 7 } & & & Ginger & Amla & Curcuma \\
\hline Liver & $2.32^{\mathrm{b}} \pm 0.15$ & $3.26^{\mathrm{a}} \pm 0.13$ & $2.64^{\mathrm{b}} \pm 0.13$ & $2.41^{\mathrm{b}} \pm 0.13$ & $2.58^{\mathrm{b}} \pm 0.09$ & $2.30^{\mathrm{b}} \pm 0.07$ \\
Kidney & $0.59^{\mathrm{b}} \pm 0.03$ & $0.81^{\mathrm{a}} \pm 0.08$ & $0.68^{a b} \pm 0.05$ & $0.61^{\mathrm{b}} \pm 0.07$ & $0.62^{\mathrm{b}} \pm 0.04$ & $0.59^{\mathrm{b}} \pm 0.02$ \\
\hline
\end{tabular}

- Data are presented as means $\pm \operatorname{SDM}(n=6)$.

- Means in a row with different litters are significantly different $(p<0.05)$

Table 6. Blood chemical analysis of experimental rats fed on yoghurt drink fortified with different types of herb extracts (Mean values of $6^{\text {th }}$ replicates)

\begin{tabular}{|c|c|c|c|c|c|c|}
\hline \multirow{3}{*}{ Parameters } & \multicolumn{6}{|c|}{ Groups } \\
\hline & \multirow{2}{*}{ Control (-) } & \multirow{2}{*}{ Control (+) } & \multirow{2}{*}{ Yoghurt (g) } & \multicolumn{3}{|c|}{ Yoghurt + different types of herb extracts } \\
\hline & & & & Ginger & Amla & Curcuma \\
\hline \multicolumn{7}{|c|}{ Liver enzyms (U/I) } \\
\hline ALT & $44.00 \pm 2.309^{c}$ & $92.00 \pm 3.464 \mathrm{a}$ & $57.67 \pm 4.63^{\mathrm{c}}$ & $74.33 \pm 7.796^{b}$ & $55.33 \pm 3.333^{c}$ & $57.67 \pm 2.028^{c}$ \\
\hline AST & $59.33 \pm 4.055^{\mathrm{e}}$ & $134.7 \pm 11.55^{\mathrm{a}}$ & $97.33 \pm 1.453 \mathrm{bc}$ & $106.3 \pm 5.925^{b}$ & $83.00 \pm 9.074^{\mathrm{cd}}$ & $71.33 \pm 3.756^{\mathrm{ed}}$ \\
\hline TP & $6.133 \pm 0.033^{b}$ & $5.867 \pm 0.067^{a}$ & $5.833 \pm 0.088^{a}$ & $5.800 \pm 0.208^{a}$ & $5.867 \pm 0.318^{\mathrm{a}}$ & $6.167 \pm 0.120^{b}$ \\
\hline \multicolumn{7}{|c|}{ Kidney function $(\mathrm{mg} / \mathrm{dl})$} \\
\hline Urea & $34.00 \pm 3.512^{b}$ & $47.33 \pm 5.175^{\mathrm{a}}$ & $44.00 \pm 5.292 \mathrm{ab}$ & $42.67 \pm 1.667^{\mathrm{ab}}$ & $43.00 \pm 2.082^{\mathrm{ab}}$ & $39.33 \pm 3.180^{\mathrm{ab}}$ \\
\hline Uric Acid & $2.267 \pm 0.120^{a}$ & $2.300 \pm 0^{a}$ & $2.333 \pm 0.176^{a}$ & $2.167 \pm 0.088^{a}$ & $2.333 \pm 0.176^{\mathrm{a}}$ & $2.167 \pm 0.088^{a}$ \\
\hline Creatinine & $0.590 \pm 0.020^{b}$ & $0.840 \pm 0.020^{a}$ & $0.780 \pm 0.081 \mathrm{ab}$ & $0.800 \pm 0.035^{a b}$ & $0.783 \pm 0.125^{\mathrm{ab}}$ & $0.763 \pm 0.050^{\mathrm{ab}}$ \\
\hline
\end{tabular}

- Data are presented as means $\pm \operatorname{SDM}(n=6)$.

- Means in a row with different litters are significantly different $(p<0.05)$

- AST, ALT and TP means aspartate amino transferase, alanine amino transferase and total protein, respectively.

on yoghurt drink fortified with different types of herb extract. The highly significant decrease $(P<0.05)$ was observed in yoghurt drink + curcuma extract. As compared to control (+) group. (Yokozawa et al 2003) reported that renal dysfunction can be detected by evaluating the level of urea concentration and the correlation between the severity of the pathological condition and the concentration of blood urea nitrogen is potentially relatively good.

\subsection{Histopathological examination}

Organs such as liver and kidney were examined by a histological approach and the photomicrographs of hematolxylin - eosin stained are illustrated in Figs. (1 to 4).

\subsubsection{Liver}

Histopathological examination of the liver sections from control - (normal rats fed on commercial diet only) showed no histopathological alteration and the normal histological structure of the central vein and surrounding hepatocytes in the parenchyma (Fig. 1.A). While in the control (+) group (normal rats fed on commercial diet + injection with $\mathrm{CCl}_{4}$ ) focal fibrosis was observed also in between the hepatocytes in focal manner (Fig. 1.B1), the portal area showed oedema with few inflammatory cells infiltration (Fig. 1.B2). And there were sever congestion in the central vein (Fig. 1.B3). The animals affected by $\mathrm{CCl}_{4}$ plus fed on (drink yoghurt only) showed inflammatory cells infiltration in the portal area, as well as fibroblastic cells 

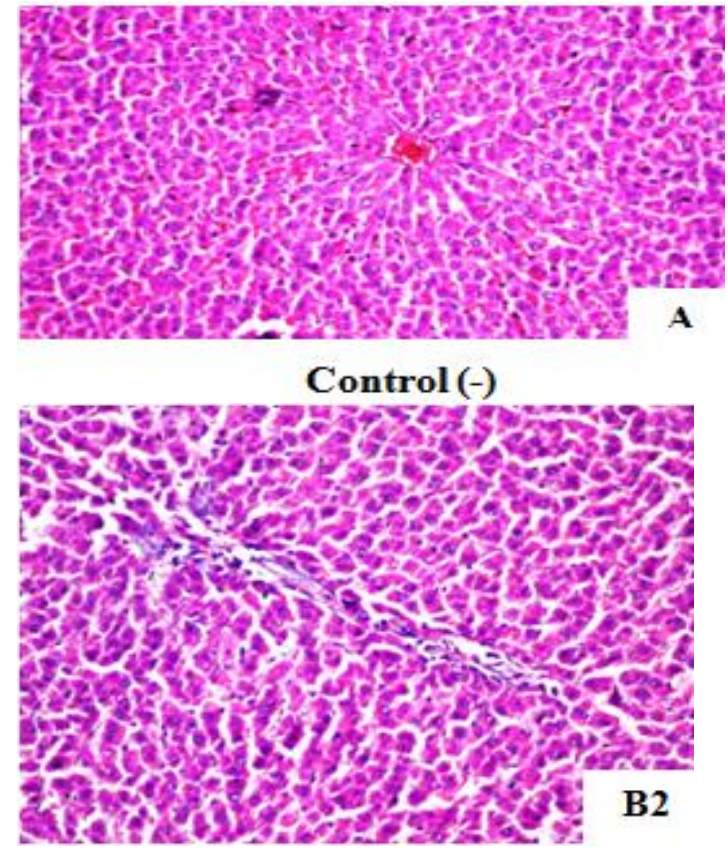
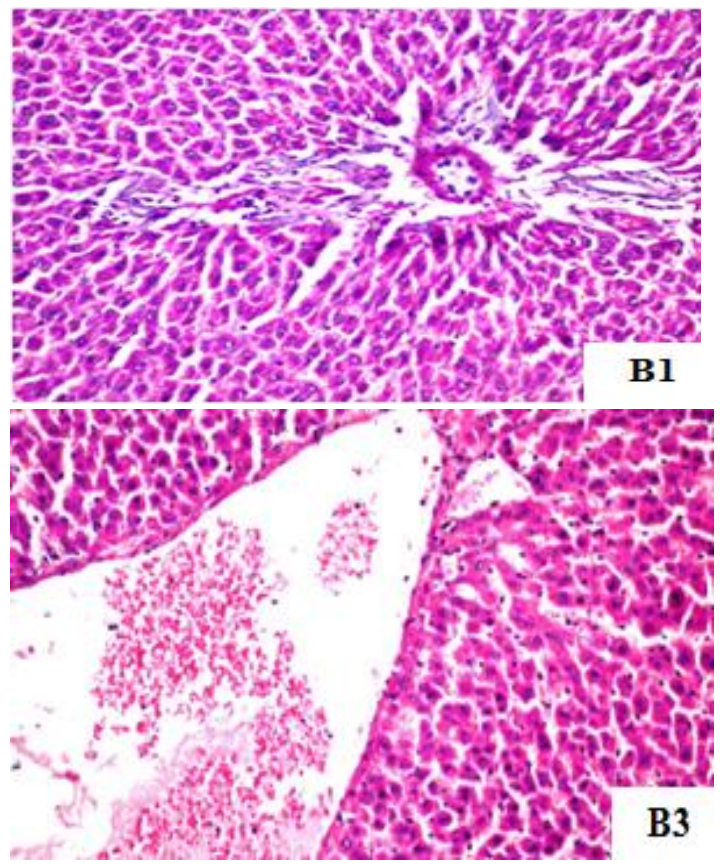

Fig. 1. Photomicrograph of liver Sections in (control (-) and control (+) groups) (H\&E).

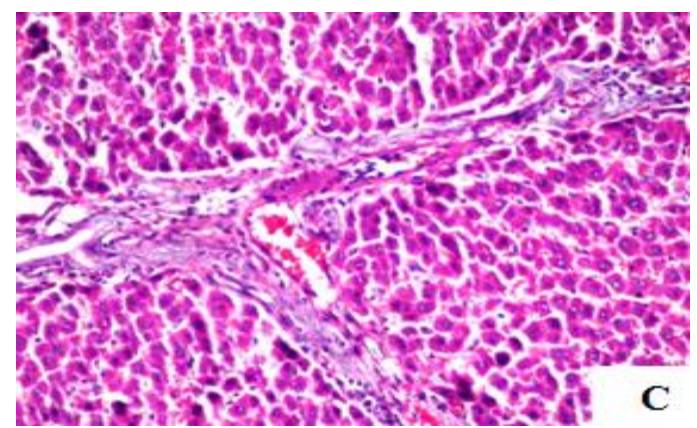
yoghurt drink

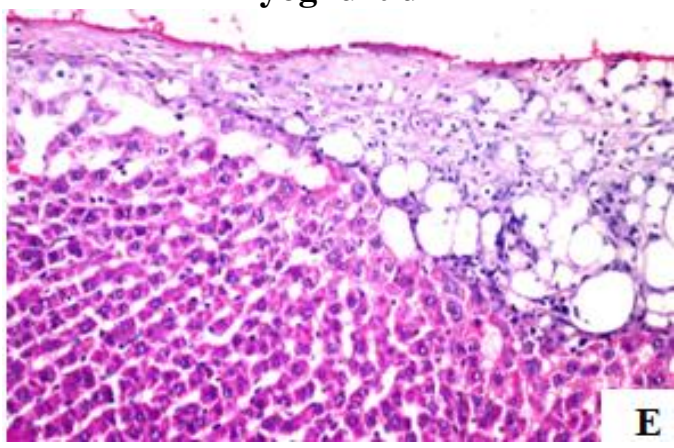

yoghurt drink + Amla

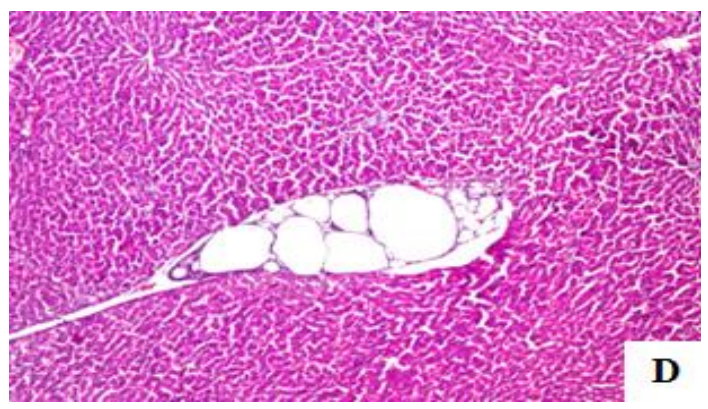

yoghurt drink + Ginger

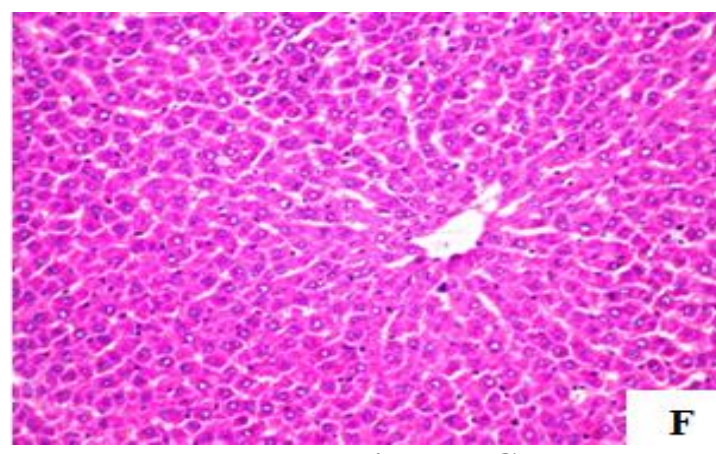

yoghurt drink $\mathbf{t}+$ Curcuma

Fig. 2. Histological changes in liver on injected rats fed on yoghurt drink fortified with different types of herb extract $(30 \%)$ with $(\mathrm{H} \& \mathrm{E})$ 
Production of Function yoghurt drink fortified with different types of herbal extracts and its biological attributes in hepatitis rats

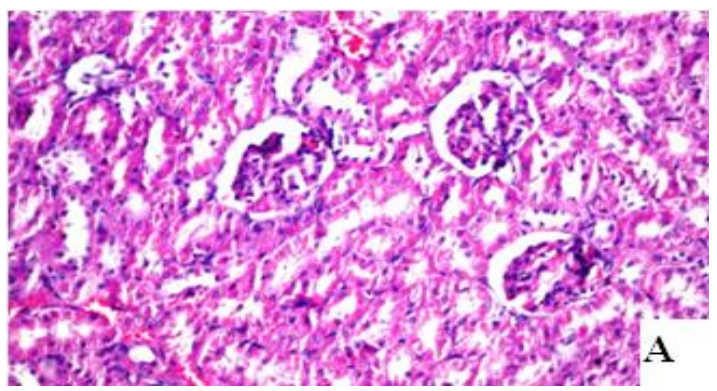

Control (-)

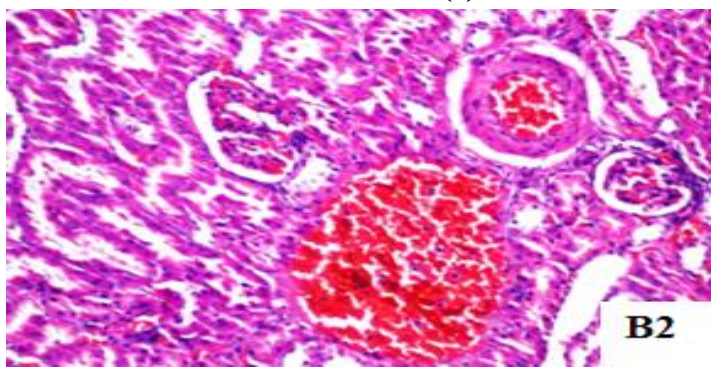

B2

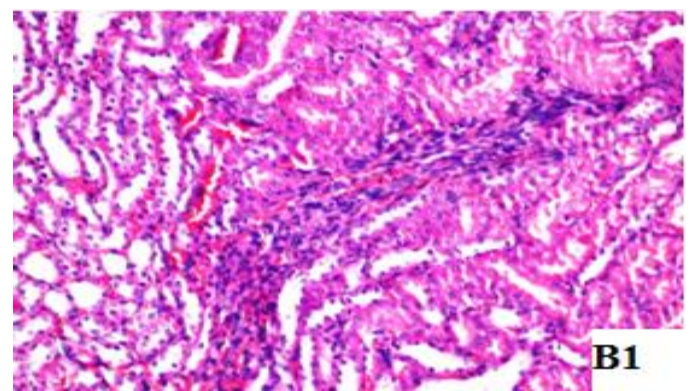

B1

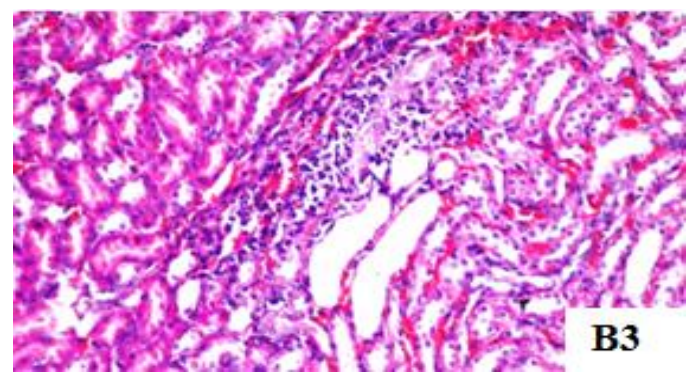

Control (+)

Fig. 3. Photomicrograph of kidney sections in (control (-) and control (+) groups) with (H\&E).

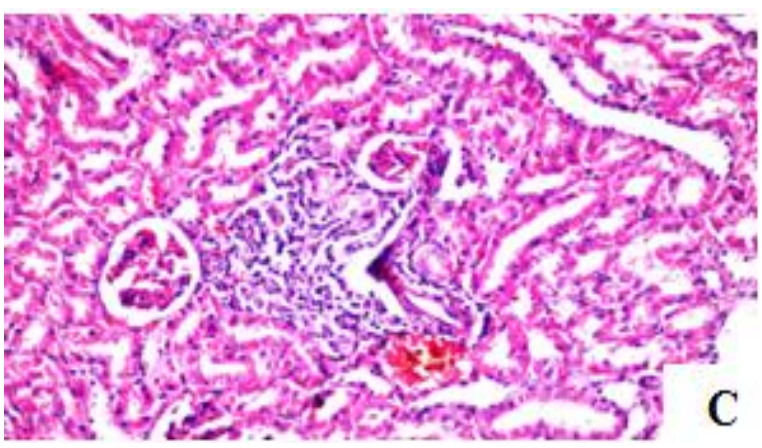

yoghurt drink

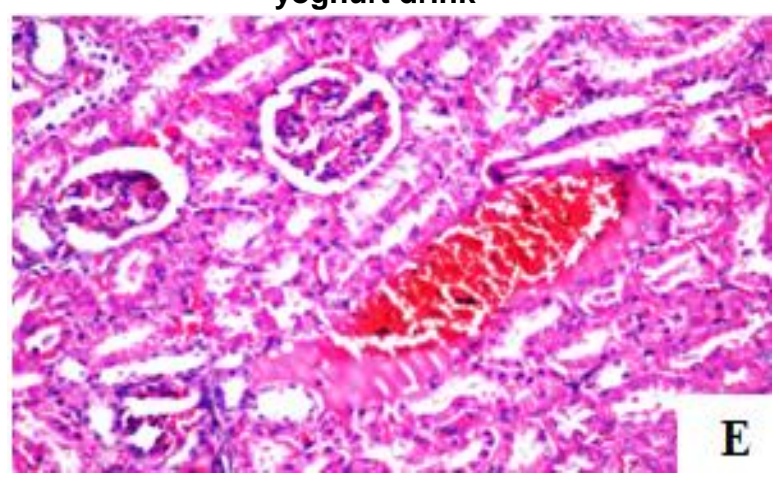

yoghurt drink +Amla

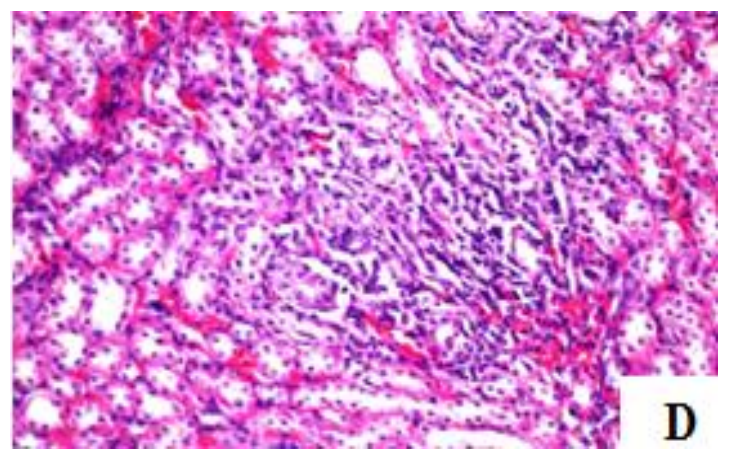

yoghurt drink +Ginger

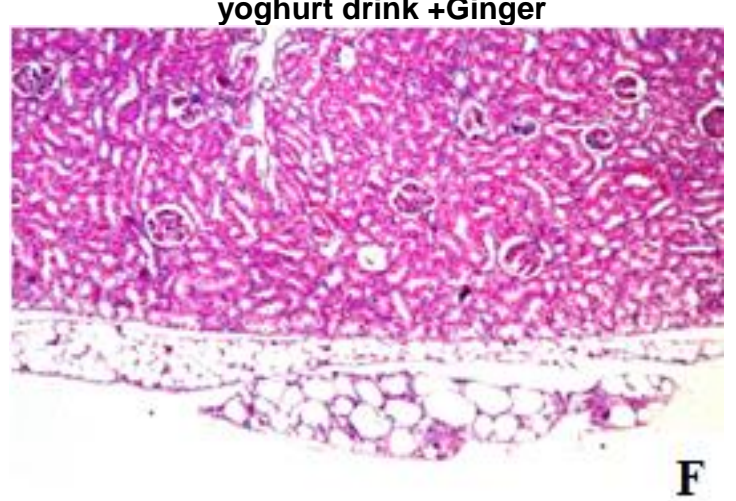

yoghurt drink $t+$ Curcuma

Fig. 4. Histological changes in kidney on injected rats fed on yoghurt drink fortified with different types of herb extracts with $(\mathrm{H} \& \mathrm{E})$. 
proliferation as seen in (Fig.2.C). Steatosis was observed in focal manner between the hepatocytes at (Fig. 2.D) in the animals affected by $\mathrm{CCl}_{4}$ plus fed on (drink yoghurt $+30 \%$ ginger extract). The result of this spectrophotometry supported the result of the histopathology of liver and these may be attributed to ginger components which may stabilize hepatocytes plasma membrane and prevent delivery of ALT to the extracellular fluid (Ajith et al 2007). Liver of injected rats by $\mathrm{CCl}_{4}$ plus fed on (drink yoghurt $+30 \%$ amla extract) showed fatty change in the hepatocytes at the periphery of the lobules as seen in (Fig. 2.E). In contrast, no histopathological alteration were observed in the animals affected by $\mathrm{CCl} 4$ plus fed on (drink yoghurt $+30 \%$ Curcuma extract) as seen in (Fig. 2.F).

\subsubsection{Kidney}

The rats fed on commercial diet only (control (-)) showed no histopathological changes and the normal histological structure of the glomeruli and tubules at the cortex (Fig. 3A). While animals fed on commercial diet + injection with $\mathrm{CCl}_{4}$ focal fibrosis was observed also in between the hepatocytes in focal manner (Fig. 3B1). also observed oedema with few inflammatory cells infiltration in the portal area (Fig. 3B2) and there were sever congestion in the central vein as seen in Fig. (3B3).

Furthermore, kidney of animals affected by $\mathrm{CCl}_{4}$ plus fed on (drink yoghurt only) as seen in (Fig. 4C), showed focal inflammatory cells infiltration in the cortical portion. While the animals affected by $\mathrm{CCl}_{4}$ plus fed on (drink yoghurt $+30 \%$ ginger extract) as seen in (Fig. 4D), the corticomedullary portion had focal inflammatory cells infiltration. Also kidney of injected rats by $\mathrm{CCl}_{4}$ plus fed on (drink yoghurt $+30 \%$ amla extract) observed Steatosis in the capsule associated with congestion in the cortical blood vessels in (Fig. 4E) In contrast, animals affected by $\mathrm{CCl}_{4}$ plus fed on (drink yoghurt $+30 \%$ Curcuma extract) as seen in (Fig. 4F), observed Steatosis in the renal capsule.

\section{CONCLUSION}

Based on the previous results, it can be reported that different types of herbs extract (Ginger, Amla and Curcuma) could be used in production of functional herbal yoghurt drink characterized with high content of antioxidant. These drinks can be used to protect liver against the oxidative stress of $\mathrm{CCl}_{4}$. yo- ghurt drink fortified with Curcuma was highly effective than yoghurt drink fortified with amla or ginger. Therefore, drinking yoghurt fortified with different herbal extract especially Curcuma extract could be used as a functional food for some individuals who suffering liver diseases.

\section{REFERENCES}

Ajith T.A., Hema U. and Aswathy M.S., 2007. Zingiber officinale Roscoe prevents acetaminophen-induced acute hepatotoxicity by enhancing hepatic antioxidant Status. Food and Chemical Toxicology. 45, 2267-2272.

AOAC 2012. Official Methods of Analysis. $18^{\text {th }}$ ed. AOAC International Gaithersburg MD. No. (9685-080), and CH.4, pp. 56-57 and No. (985.01) Ch.3, 6 p.

Barham D. and Trinder P. 1972. An improved colour reagent for the determination of blood glucose by the oxidase system. Analyst, 97, 142145.

Barta A., Janega P., Babál P., Murár E., Cebová M. and Pechánová O. 2015. The effect of curcumin on liver fibrosis in the rat model of microsurgical cholestasis. Food Function. 6(7), 2187-2193.

Benzie I.F.F. and Strain J.J. 1996. The ferric reducing ability of plasma (FRAP) as a measure of "antioxidant power": the FRAP assay. Analytical Biochem. 239, 70-76.

Chapman D.G., Gastilla R. and Campbell J.A. 1959. Evaluation of protein in food I.A. Method for the determination of protein efficiency ratio. Can. J. Biochem Physiol. 37, 679-686.

Davinder K. 2012. Assessment of quality and stability of ginger incorporated ice cream. Master of Science in food technology, Department of Food Science and Technology, Fac. of Agric., Punjab Agricultural Ludhiana, 21 p.

El-Samahy S.K., Gaballah A.A., Embaby H.E., Hamed Y.S. and Khalil R.A.M. 2014. Improving the nutritional value and quality of yoghurt drink by using cactus pear (Opuntai dillenii) pulp. Egypt. J. Dairy. Sci. 42, 133-144.

Fawcett J.K. and Soctt J.E. 1960. A rapid and precise method for the determination of urea. $\mathbf{J}$. Clinc., Path. 13, 156-159.

Frey R.J. 2007. Blood urea nitrogen test health article. http://healthline.com/galecontent/blood urea-nitrogen-test. 
Production of Function yoghurt drink fortified with different types of herbal extracts and its biological attributes in hepatitis rats

Gharibzahedi S.M.T. and Chronakis I.S. 2018. Crosslinking of milk proteins by microbial transglutaminase: utilization in functional yogurt products. J. Food Chem., 245, 620-632.

Hallim A.M., Rabie A., Madiha A.ES. and Azza S.AG. 2019. Evaluation of physico-chemical properties and antioxidant activity of stirred yoghurt fortified with pomegranate and cactus pear juices. Zagazig J. Agric. Res. 46(6A), 1-14.

Huo H.Z., Wang B., Liang Y.K., Bao Y.Y. and Gu Y. 2011. Hepatoprotective andantioxidant effects of licorice extract against $\mathrm{CCl} 4$-induced oxidative damage inrats. Int. J. of Molecular Sci. 12, 6529-6543.

Jain S.K. and Khurdiya D.S. 2004. Vitamin C enrichment of fruit juice based ready to serve beverages through blending of Indian gooseberry (Emblica officinalis). J. Plant Foods for Human Nutrition. 59(2), 63-66.

Jayasekhar P., Mohanan P.V. and Rahinam K. 1997. Hepatoprotective activity of ethyl acetate extract of acacia catechu. Indian. J. Pharmacology. 29, 426-428.

Kazeem M.I., Bankole H.A. and Fatai A.A. 2011. Protective effect of ginger in normal and carbontetrachlorideinduced hepatotoxic rats. Ann Biol Res., 2(1), 1-8.

Lalita O., Jana A., Prajapati P.S. and Priyanka S. 2017. Application of herbs in functional dairy products. J. of Dairy Veterinary and Animal Research, 5(3), 145-151.

Maduka H.C.C., Daja A., Gadaka G.A., Ugwu C.E., Dike C.C., Ababaker K.A. and Maduka A.A. 2014. Protective Role of Morning Oleifera Lam Aqueous Leaf Extract on some Excretory products and Hematological Parameters in Acetaminophen Induced Albino Rats. IOSR J. of Nursing and Health Sci., 3, 27-31.

Mahmoud A.E., Sahar M. and Faten S. 2012. Production and Evaluation of Soft Cheese Fortified with Ginger Extract as a Functional Dairy Food. Pol. J. Food Nutr. Sci. 62, 77-83.

Maizura M., Aminah A. and Wan Aida W.M. 2011. Total phenolic content and antioxidant activity of kesum (Polygonum minus), ginger (Zingiber officinale) and turmeric (Curcuma longa) extract. Int. Food Research J. 18, 529-534.

Maksimovic Z., Malenci D. and Kovacevi N. 2005. Polyphenol contents and antioxidant activity of Maydis stigma extracts. Bioresource Technology. 96. 873-887,
Morisco F., Vitaglione P., Amoruso D., Russo B. and Fogliano V.N. 2008. Foods and liver health. Molecular Aspects of Medicine. 29.144-150.

Odabasoglu F., Aslan A., Cakir A., Suleyman H., Karagoz Y. and Halici M. 2004. Comparison of antioxidant activity and phenolic content of three lichen species. Phytotherapy Research. 11, 938-941.

Pohjanheimo T. and Sandell M. 2009. Explaining the liking for drinking yoghurt: The role of sensory quality, food choice motives, health concern and product information. International Dairy J., 19(8), 459-466.

Raushan K., Shashi K.B., Vikash K. and Nirmala A. 2013. Antioxident Activtiy \& Cytotoxic Analysis of Seed Extract of Punica Granatum. Asian. J. of Biochemical and Pharmaceutical Research 1(3), 2231-2560.

Reitman A. and Franklel S. 1957. A colorimetric method for the determination of serum glutamic oxalacetic and glutamic pyruvic transaminases. Amer. J. Clinc. Path. 28(1), 56-63.

Ross S. 2000. Functional foods; the food and Drug adminis tration perspective. Amer. J. Clin. Nutr. 71, 1735-1738.

SAS 1999. User's Guide Statistics. SAS Institute Inc. Editors, Cary, NC.

Shetty K., Apostolidis E. and Kwon Y.I. 2007. Inhibitory potential of herb, fruit, and fungal-enriched cheese against key enzymes linked to type 2 diabetes and hypertension. Innov. Food Sci. Emerg. Technol. 8, 46-54.

Swelem S.E. 2015. Studies on herbal drinking yoghurts. M. Sci.., Food Sci. Dept., Fac. of Agric., Ain Shames Univ., Cairo, Egypt. 68 p.

Thomas N. and Wansapala M.A.J. 2017. Utilization of green tea (Camellia Sinensis) extract for the production of antioxidant rich functional drinking yoghurt. Int. J. of Food Sci. and Nutrition, 2(1), 188-195.

Ugwuja E.L., Ugwu N.C. and Nwibo A.N. 2008. Dietary supplement containing mixture of raw curry, garlic, and ginger. Int. J. Nutration., 5, 35-42.

Vijayalakshmi V.I., Stuart C.S. and Shirani G. 2014. Consumer acceptability and antioxidant potential of probiotic-yogurt with spices. LWT. Food Sci. and Technology. 55, 255-262.

Yokozawa T., Cho E. and Nakagawa T. 2003. Influence of green tea polyphenol in rats with arginine-induced renal failure. J. Agric. Food Chem. 51, 2421-2425. 


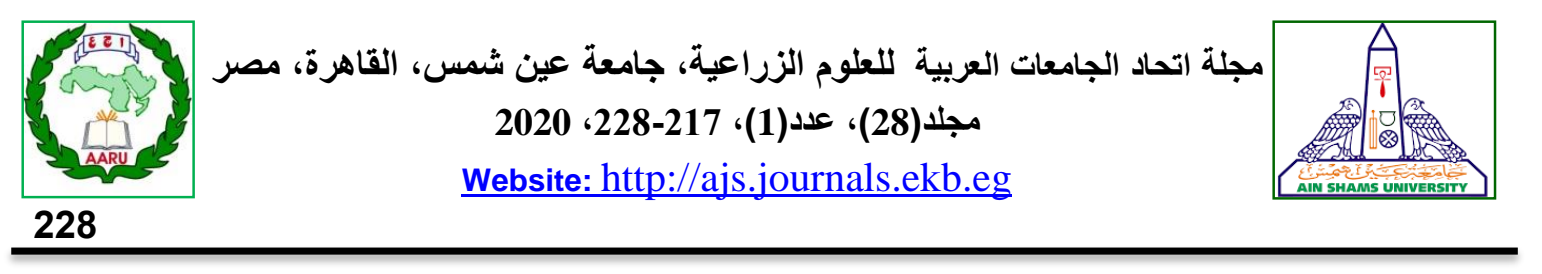

$$
\begin{aligned}
& \text { محمد السعودى1" - أسامة إبراهيم البطاوي2 - عبد الفتاح عبد الكريم2 - } \\
& \text { صفاء طلعت جوهرى3 - وحيد إبراهيم الاسوقى } 1 \text { - } 1 \text { إبطائ } \\
& \text { 1-قسم علوم الألبان - كلية الزراعة - جامعة الأزهر - فرع أسيوط - مصر جره }
\end{aligned}
$$

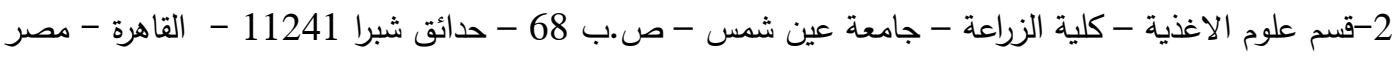

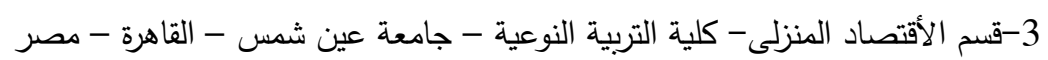

*Corresponding author: Alsoudymohamed@gmail.com

اليوجهورت السادة ومشروبات اليوجهورت المدعمة الاعتابة

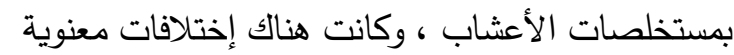

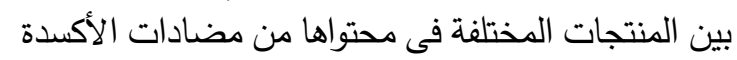

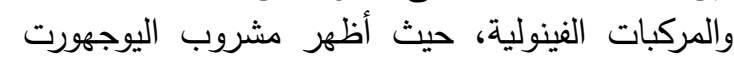

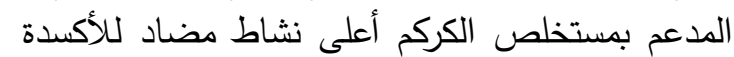

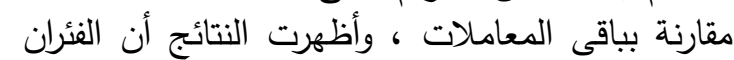

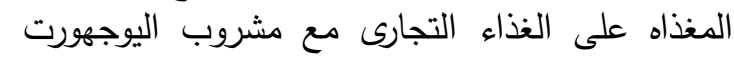

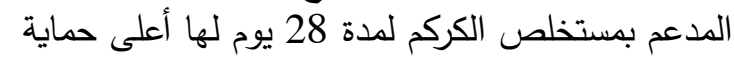

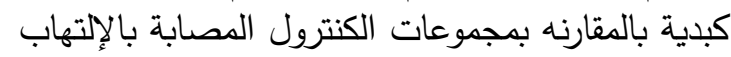
الكبدى حيث أنها إستعادت وظائفها الحيوية وكذلك الكية

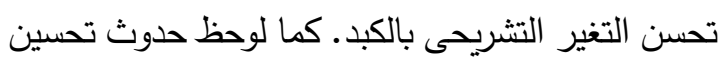

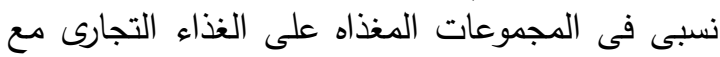

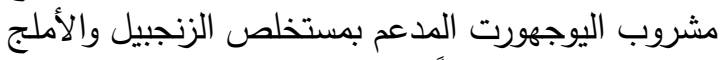

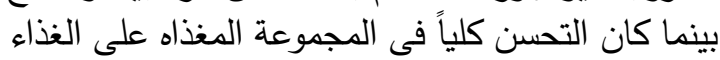

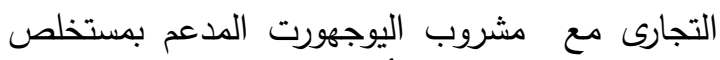
الكركم. ويمكن التوصية بأن مشروب اليوجهورب الدئمرت المدعم

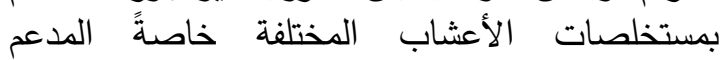

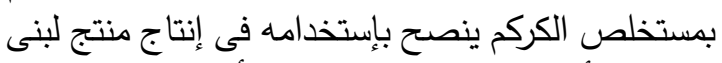
وظيفى للأشخاص الذين يعانون من أمراض الكبد.

الكلمات المفتاحية: الإلتهاب الكبدى، رابع كلوريد

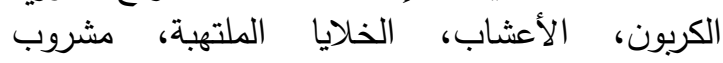
اليوجهورت المدعم بمستخلصات الأعشاب الماباب

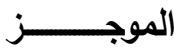

تهدف هذه الدراسة الى انتاج مشروب يوجهورت وظيفى مدعم بأنواع مختلفة من مستخلصات النتات الأعشاب

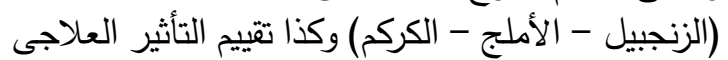

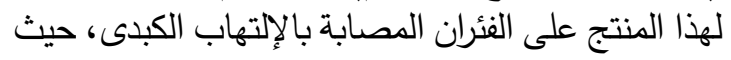

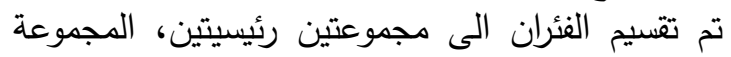

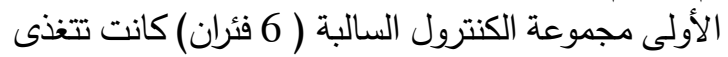

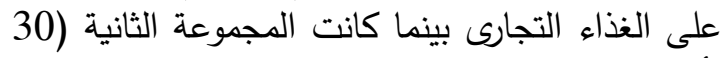

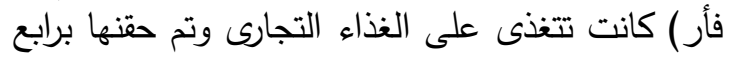

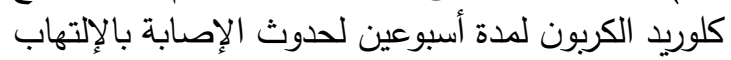

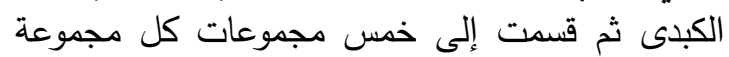
كانت تحتوى على ستة فئران وقد تمت المعلى المعاملة بواسطة

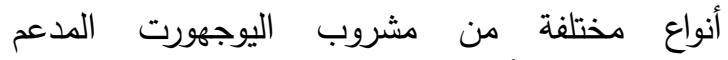
بمستخلصات الأعثاب المختلفة، حيث تم تقدير نشاط النداط

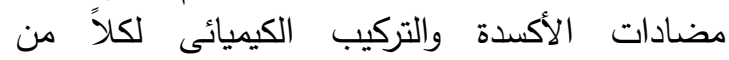
المستخلصات والمنتج النهائى وكذللك تقييم التأثير العلاجي لمشروب اليوجهورت المدعم بالمستخلصات المئي على الفئران المصابة بالإلتهاب الكبدى الكرون الناتج من تأثير

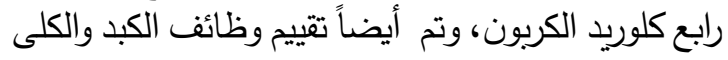

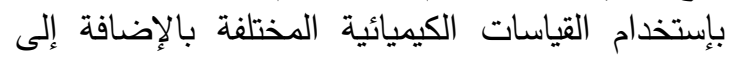

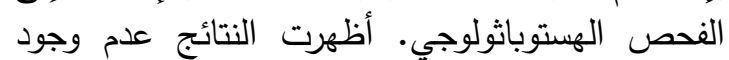
إختلافات معنوية فى الخواص الكيميائية بين مشروبات 
